\title{
ANALYZING DEFORMATION WITHIN A NORMAL FAULT TRANSFER ZONE USING SFM 3D MODELING
}

CAROLINE MCKEIGHAN, Trinity University

Research Advisor: Benjamin Surpless

\section{INTRODUCTION}

Segmented normal fault systems increase the complexity and development of subsidiary structures such as joints, minor faults, and deformation bands. Where fault segments overlap, shear stresses are highest near the segment tips (e.g., Cowie and Shipton, 1998; Schiefelbein, 2002;), and as fault segments propagate and begin to interact, their paths may be deflected by local stress fields associated with other segments (e.g., Reber, 2001; Schiefelbein, 2002). Prior to linking, the structural discontinuity between the faults' propagating tips is a zone of distributed strain, a transfer zone (e.g., Taylor and Stewart, 1996; Ferrill and others, 1999), that commonly alters the mechanical and hydrologic properties of the rock (e.g., Davatzes, 2005). In many cases, these zones of amplified stress display fracturing (e.g. Davis, 1999) that may vary significantly depending on factors such as thickness of the beds, the weak or strong nature of the contact between beds, and other material properties of each layer (e.g., Cooke et al., 2000; McGinnis et al., 2015).

Thus, in transfer zones, where fracturing is commonly of higher intensity, fluid flow and permeability may be significantly enhanced, which impacts ore deposit formation, groundwater flow, and hydrocarbon migration (e.g., Sibson, 1987). In this study, we compare deformation within a well-documented normal fault transfer zone to deformation at a locality where a single fault accommodates all extension.

\section{STUDY AREA}

In southcentral Utah, three major high-angle normal faults, including the Sevier fault zone, accommodate strain across the transition zone between the raised and relatively stable Colorado Plateau to the west and the highly-extended Basin and Range province to the east (e.g. Davis, 1997; Schiefelbein, 2002). The Orderville Salient, near the city of Orderville, Utah, displays two normal fault transfer zones along the Sevier fault zone (e.g., Schiefelbein, 2002). We focus on one of these transfer zones, located in Red Hollow Canyon, where two fault segments overlapped and linked (Reber et al., 2001; Schiefelbein, 2002) (Fig. 1). We also investigate strain accommodated by a single fault at Elkheart Cliffs, where the Mt. Carmel Segment of the Sevier fault zone is exposed (e.g., Schiefelbein, 2002).

The oldest sedimentary rock in the exposed stratigraphy is the Jurassic Navajo sandstone, which consists of a thick, cross bedded, fine- to mediumgrained, well-sorted, and well-rounded quartz sandstone; the sandstone consists of a lower, red, oxidized unit and an upper, light-gray, bleached unit (e.g., Gregory, 1951; Hintze, 1973; Peterson and Pipiringos, 1979; Sargent and Philpott, 1987; Schiefelbein, 2002). Unconformably overlying the Navajo Sandstone is the Carmel formation, which is made up of alternating siltstone and limestone (e.g., Gregory, 1951; Hintze, 1973; Sargent and Philpott, 1987; Schiefelbein, 2002).

At both locations, I analyze the three-dimensional fracture network, focusing on lateral and vertical variations in fracture orientation and intensity. I also relate changes in fracture patterns to lithologic differences between exposed rock units, thus building a more complete picture of the relationship between normal faulting and fracturing. In order to achieve 
these goals, I designed a workflow that has allowed me to construct 3D digital models of the fault and fracture network.

\section{METHODS}

\section{Field Methods}

In the field, we documented the position of fractures along scanlines oriented perpendicular to fracture strike. We only documented fractures with vertical height of greater than 4 meters to analyze orientation, position, and characteristics of the fractures. We used field photographs and detailed field notes to document the lateral and vertical fracture network and the position within the exposed stratigraphy. We recorded all field positions using handheld GPS units.

\section{Unmanned Aerial Vehicle (UAV)}

Although both localities display excellent bedrock exposure, the significant topography made documentation of field relationships impossible in many places. In order to gather data from the tall, vertical canyon and cliff walls, we applied an SfM (structure from motion) technique, which uses a series of overlapping photographs to create realistic digital 3D models (Johnson et al., 2014). We flew a Phantom 4 Professional UAV to record video of fault-related deformation to provide views of inaccessible lateral and vertical fracture networks associated with the Red Hollow Canyon and Elkheart Cliffs localities.

\section{D Model Workflow}

I created a workflow (Fig. 2) to build realistic, subdecimeter-resolution 3D models from videos captured during UAV flights. First, I clipped 4K images from the UAV videos at three-second intervals, using video editing software (VLC Media Player), ensuring a minimum of $70 \%$ overlap between images to guarantee accurate model building. In AgiSoft Photoscan Professional, I imported a folder of these images as a "chunk" (terminology from Agisoft Photoscan) and applied an automated lens calibration to all images. Next, I aligned the photos within the software, which created a sparse point cloud of matched points, and I georeferenced (WGS 1984/UTM Zone 12N) obvious features from these aligned photos. The program automatically attached all georeferenced markers, but I manually corrected the markers to ensure superior accuracy. Once all the markers are accurately aligned and georeferenced, I built a dense cloud. Next, I created a polygonal mesh then, I applied a texture to the mesh, based on imagery from the original-imported images, which constructs an accurate and realistic 3D model.

\section{D Model Annotation and Analysis}

After I successfully built the digital 3D model, I annotated fractures and bed contacts in Photoscan. To ensure accuracy, I used a combination of the $3 \mathrm{D}$ model and original photographs. Next, I drew scanlines perpendicular to fracture orientation and kept the height of the scanline constant relative to bed contacts. If the outcrop shape varied significantly, I segmented the scanline to follow the same vertical position within the model and to keep the scanlines perpendicular to fracture strike.

\section{RESULTS}

\section{Fracture Orientation}

I analyzed 10 field and model scanlines located within and adjacent to the Red Hollow Canyon transfer zone (Fig. 1). The easternmost scanline, F1, is in the hanging wall of the Lion's Den fault and is approximately $360 \mathrm{~m}$ above the base of the Navajo sandstone. Fractures from this scanline dominantly strike to the NNE and dip steeply $\left(>60^{\circ}\right)$ to the WNW and ESE. Scanline M1 is in the hanging wall of the Lion's Den fault, above the upper contact of the Navajo sandstone, within the basal unit of the Jurassic Carmel formation, and the dominant strike for the fracture set is to the NNE, with all fractures dipping from very steeply-WNW-dipping to vertical. Similarly, M2 is located in the hanging wall of the Lion's Den fault and the dominant fracture strike is NNE, with similar very steep to vertical dips. This scanline is stratigraphically below scanline M1 and is located approximately $545 \mathrm{~m}$ above the base of the Navajo sandstone. Scanline M3, below M2, is also located in the hanging wall of the Lion's Den fault, and is approximately $535 \mathrm{~m}$ above the base of the Navajo sandstone. The dominant fracture strike is NNE, with steep dips similar to those documented in M1 and M2. 


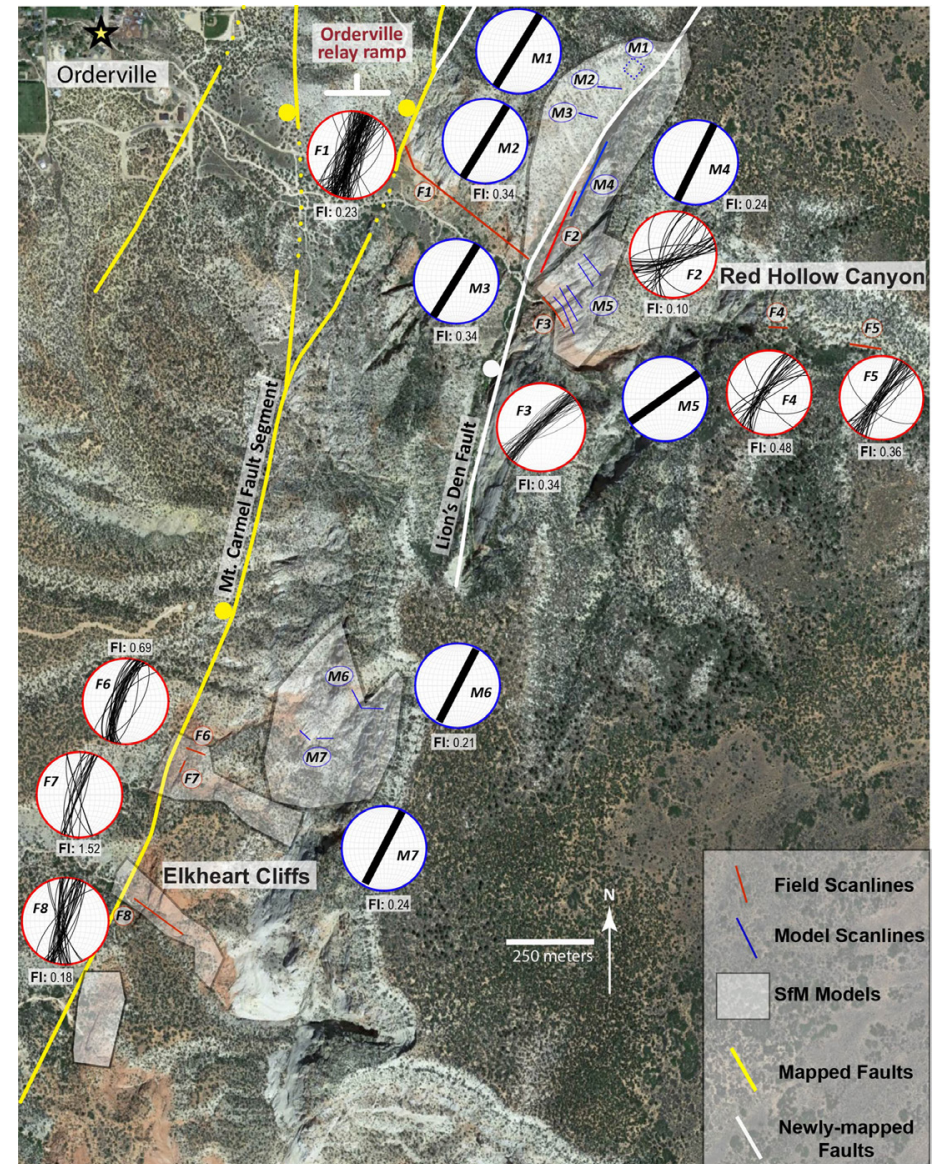

Figure 1. Orthophotograph displaying both the Red Hollow Canyon fault transfer zone to the north and Mt. Carmel segment fault locality at Elkheart Cliffs to the south. Field-based scanlines and stereonets are shown in red, and model scanlines and stereonets are shown in blue. Fracture intensity (FI) (m-1) values are included for each stereonet. 6 locations where I built highresolution SfM 3D models are outlined. The mapped and newlymapped faults run from north to south (Schiefelbein, 2002).

Scanline M4 is from the footwall of the Lion's Den fault, within less than $10 \mathrm{~m}$ from the fault contact, and is approximately 485 meters above the base of the Navajo sandstone, with fractures that strike NNE and dip very steeply to vertically (Fig. 1). Scanline F2, stratigraphically below scanline M4, is in the footwall of the Lion's Den fault, approximately $360 \mathrm{~m}$ above the base of the Navajo sandstone, and is within approximately $10 \mathrm{~m}$ of the fault contact. Fractures from this scanline display a wider range in orientations than most localities, with strikes varying from NNE to ENE (Fig. 1). These ENE-striking fractures are not consistent with most fractures from the hanging wall of the Lion's Den fault (see scanline data from F1, M1, M2, and M3; Fig. 1). These fractures dip very steeply to vertically, with a range of dips from fractures that dip to the SE to fractures that dip to the
ENE.

Scanline F3 is about $360 \mathrm{~m}$ above the base of the Navajo sandstone and is adjacent to the Lion's Den fault. The dominant strike of this fracture set is NE and fractures steeply dip SE. Scanline M5 consists of 5 scanlines from different stratigraphic positions within the Navajo sandstone, from about $400 \mathrm{~m}$ to $550 \mathrm{~m}$ above the base of the unit. Similar to scanline F3, the fractures strike to the NE. Approximately 700 meters to east of the Lion's Den fault, along two scanlines $(\mathrm{F} 4, \mathrm{~F} 5)$ the dominant fracture strike is NE, with dips that range from steeply NW- or SE-dipping to vertical. Both scanlines are about $590 \mathrm{~m}$ above the base of the Navajo sandstone; these scanlines provide the stratigraphically-highest data from the Navajo sandstone.

We also analyzed fractures from 5 scanlines along the Elkheart Cliffs, where data are from the footwall of the Mt. Carmel segment, where a single fault accommodates all extension. To the south, three scanlines, F6-F8, in the footwall of the Mt. Carmel fault segment, are located about 220 meters above the base of the Navajo sandstone, and all record similar fracture orientations; fractures along scanlines F6, F7, and F8 strike NNE and steeply dip ESE or WNW. Scanline M6 is located about $465 \mathrm{~m}$ from the base of the Navajo sandstone and the dominant strike for this fracture set is NE, with steep to vertical dips. Scanline M7 is located about $355 \mathrm{~m}$ from the base of the Navajo sandstone, and the dominant fracture strike is $\mathrm{NE}$, with all fractures displaying steep to vertical dips.

\section{Variations in Lateral and Vertical Distributions}

We found that where strain is accommodated by a single fault, the Elkheart Cliffs locality, intense fracturing and active erosion in the footwall (hanging wall rocks are not well exposed) make documentation of fractures within 30 meters of the fault impossible (Fig. 3). As shown on Scanline F8 (Fig. 3), from $~ 30$ $\mathrm{m}$ to $\sim 80 \mathrm{~m}$ from the contact, fracturing decreased in intensity with increasing distance, until fracturing sharply terminated at $\sim 120 \mathrm{~m}$ from the fault. The average fracture intensity is $0.18 \mathrm{~m}-1$ for the entire scanline (Table 1). Scanlines F6 and F7, located very close to the Mt. Carmel fault segment, have higher fracture intensities $(0.69 \mathrm{~m}-1$ and $1.52 \mathrm{~m}-1)$ than all 
other scanline locations. Across the transfer zone at Red Hollow Canyon, we found more broadly distributed fractures across $>1000 \mathrm{~m}$ with values from $0.10 \mathrm{~m}-1$ to $0.48 \mathrm{~m}-1$ that displayed no relationship between fracture intensity and position relative to the fault contact.

Using a 3D digital model of the canyon wall near the Lion's Den fault, I documented fractures along five scanlines at different stratigraphic levels within the 200-m vertical exposure (Fig. 4). Along each scanline, positions of high fracture intensity do not correlate with scanlines above or below. In addition, the average fracture intensities vary significantly throughout exposed sections with values as low as $0.20 \mathrm{~m}-1$ at scanline M5A and M5C to $0.57 \mathrm{~m}-1$ at M5B (Fig. 4). Based on field observations and digital model data, these features of the fracture network appear to be related to changes in lithology and/or cross-bed set contacts that act as barriers to vertical fracture propagation.

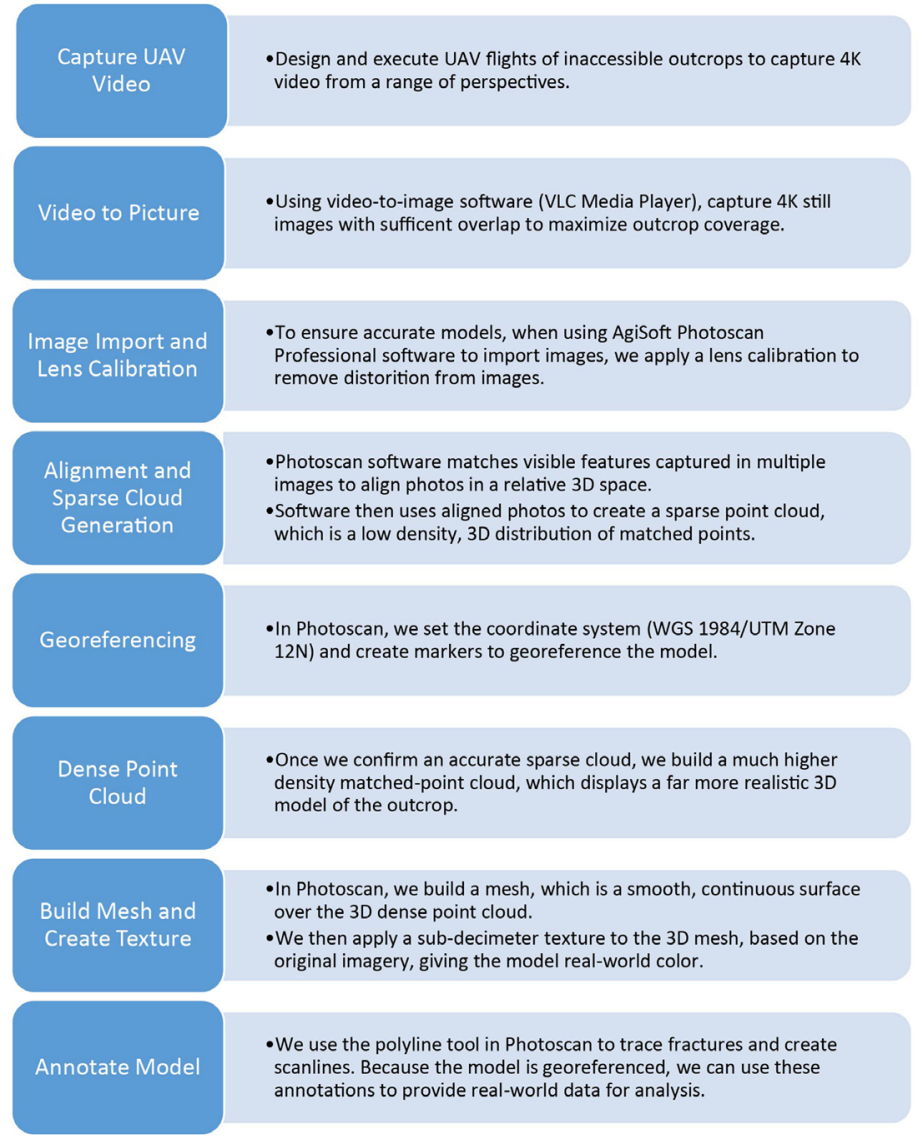

Figure 2. Workflow used to build high-resolution $3 D$ models in AgiSoft Photoscan Professional.

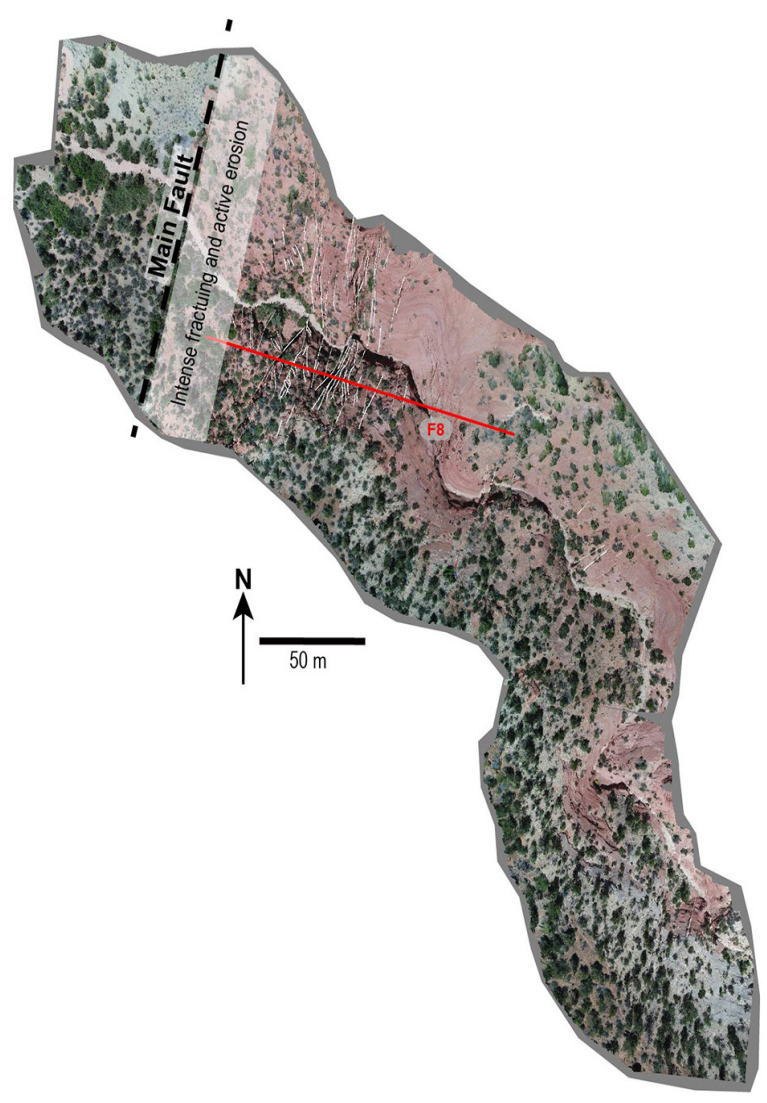

Figure 3. A high resolution 3D model of the single fault locality, the Mt. Carmel segment at Elkheart Cliffs, showing the main fault contact (dashed), fractures (white), and the field scanline F8 (red). The 30 m-wide zone of intensely-fractured rock and active erosion is highlighted.

\section{DISCUSSION}

At Elkheart Cliffs, fracture orientations from all field and model scanlines are sub-parallel to the Mt. Carmel fault segment, dipping the same direction as the fault. This includes scanlines M6 and M7, which are more than $250 \mathrm{~m}$ from the Mt. Carmel segment, suggesting that nearly all fractures formed in the same stress field as the fault, without any significant variations in local stresses. Similarly, in the Red Hollow Canyon transfer zone, fractures from scanlines F1 and M1-M4 strike NNE, sub-parallel to most faults across the transfer zone, suggesting fracture formation at those localities was nearly identical to that responsible for fault formation. However, to the east of the west-dipping Lion's Den fault, there is a $10-15^{\circ}$ degree difference in the strike (NE) of fractures on scanlines F3-F5 and M5, with scanline F2, located within $10 \mathrm{~m}$ of the Lion's Den fault, displaying fractures with an even greater difference, $\sim 20^{\circ}$, in fracture strike (ENE). 

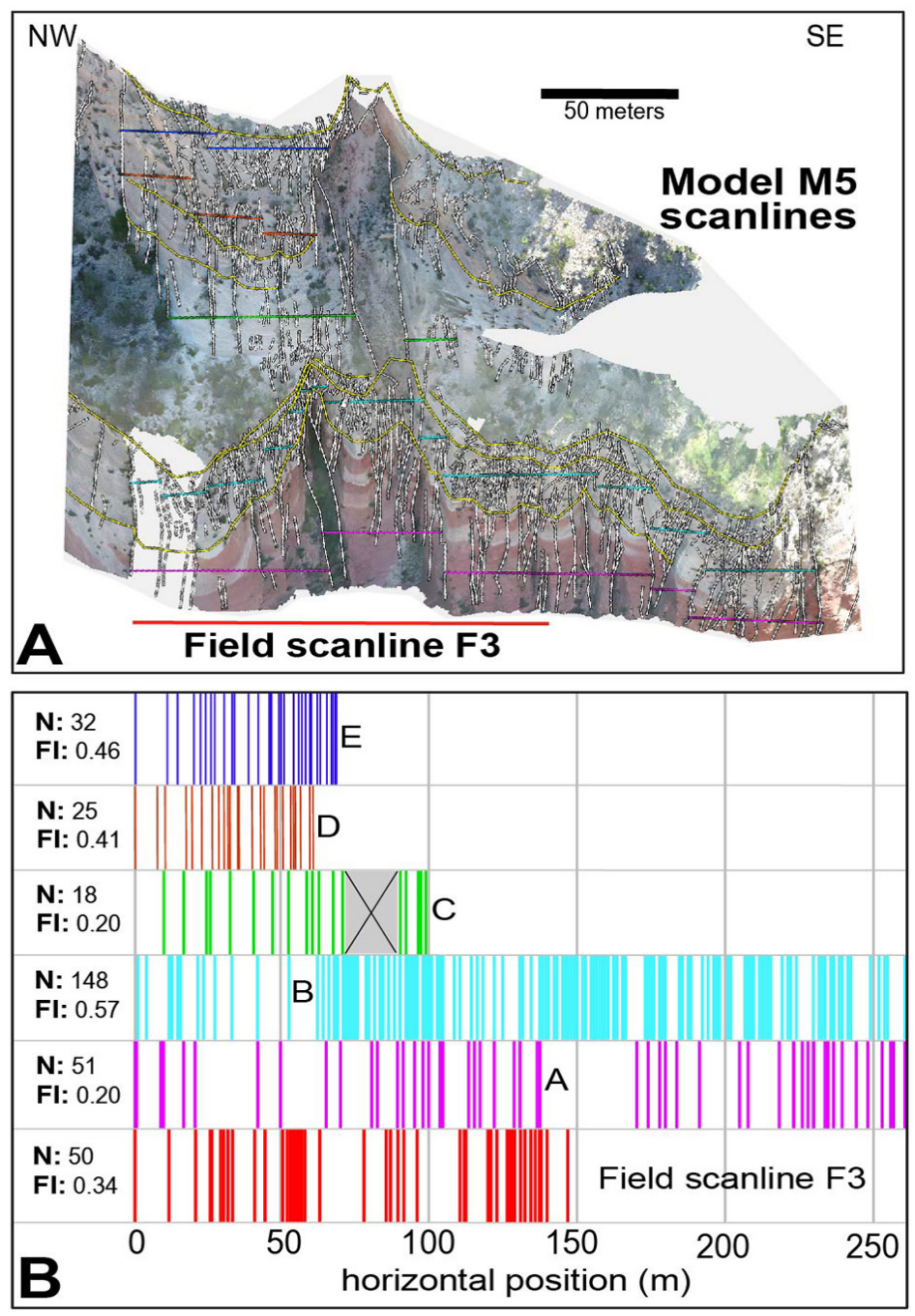

Figure 4. Transfer zone location displaying multiple scanlines. A. 5 vertically-stacked model scanlines, at location M5, including field scanline, F3. Scanlines are displayed on a screenshot of the $3 D$ model built for this location. The model displays fractures (white) and bedding or changes in lithology (yellow). B. Fracture position with number of fractures measured $(N)$ and fracture intensity (FI) $(m-1)$.

I suggest that the Elkheart Cliffs fracture set is concurrent with the formation of the Mt. Carmel fault segment. However, further north, in Red Hollow Canyon, differences in fracture orientation laterally across Lion's Den fault indicate a more complicated fracture network with fractures that formed at different times relative to the faults. Fractures on the hanging wall, with the same orientation as the Lion's Den fault, likely formed at the same time as this fault and others in the transfer zone formed. Fractures that display different orientations, in the footwall of the fault, likely formed after the formation of the Lion's Den fault, with the fault acting as a stress barrier, preventing formation of fractures of those orientations in the hanging wall.
Importantly, fractures at all locations dip steeply $\left(>60^{\circ}\right)$, indicating a stress field consistent with mixed mode failure in a tensile transitional stress field, with the minimum stress (tensional) oriented perpendicular to fracture strike. This stress field orientation is consistent with stresses responsible for Basin and Range extension in this region (e.g., Rogers et al., 2004), and the tensional minimum stress field is consistent fractures formed close to the surface, or at shallow depths with increased pore fluid pressures.

Fractures at the Red Hollow Canyon transfer zone locality are more broadly distributed, without changes in intensity associated with exposed faults, while at the single fault locality, Elkheart Cliffs, fracture intensity decreased rapidly with distance from the fault contact, with most fracturing focused adjacent to the fault contact. Thus, it is likely that the lateral distribution of stresses through rock volumes varied significantly between the two structural settings, creating fundamentally different fracture networks.

\section{At Red Hollow Canyon, our data from different} stratigraphic positions suggest that average fracture intensity and the position of high-intensity fracturing varies significantly in spite being in the same structural position relative to the Lion's Den fault. The significant variability from one vertical position to the next was most likely controlled by a combination of different mechanical behaviors (e.g., different elastic moduli) and by bed contacts within the Navajo sandstone acting as mechanical barriers to fracture propagation (e.g., McGinnis et al., 2015).

If the fracture network documented here was in the subsurface, our fracture data support a model where fluid flow would depend on structural position. At the transfer zone locality, the broader distributed fracture network would be expected to create a wide but diffuse zone of fluid flow, while the narrower but more intensely fractured zone adjacent to the single fault might create a more localized but perhaps more permeable pathway for fluids. The changes in the vertical fracture network is more complex, with a lack of vertical persistence through the stratigraphy. Although there were horizons with higher fracture intensities, these locations would be difficult to predict in the subsurface, and prediction of vertical connectivity of fluid pathways would also 
Table 1. Fracture intensity (F.I.) values for field and model scanlines within the Jurassic Navajo sandstone.

\begin{tabular}{|c|c|c|c|c|c|c|c|c|c|c|c|c|c|c|c|c|c|c|}
\hline \multirow{3}{*}{$\begin{array}{l}\text { Scanline } \\
\text { Locations }\end{array}$} & \multirow{3}{*}{ F1 } & \multirow{3}{*}{ F2 } & \multirow{3}{*}{ F3 } & \multicolumn{5}{|c|}{ Red Hollow Canyon } & & & & & & \multicolumn{5}{|c|}{ Elkheart Cliffs } \\
\hline & & & & \multirow{2}{*}{ F4 } & \multirow{2}{*}{ F5 } & \multirow{2}{*}{ M2 } & \multirow{2}{*}{ M3 } & \multirow{2}{*}{ M4 } & \multicolumn{5}{|c|}{ M5 } & \multirow{2}{*}{ F6 } & \multirow{2}{*}{ F7 } & \multirow{2}{*}{ F8 } & \multirow{2}{*}{ M6 } & \multirow{2}{*}{ M7 } \\
\hline & & & & & & & & & A & B & $\mathrm{C}$ & $\mathrm{D}$ & $\mathrm{E}$ & & & & & \\
\hline $\begin{array}{l}\text { Average } \\
\text { F.I. }\left(\mathbf{m}^{-1}\right)\end{array}$ & 0.23 & 0.10 & 0.34 & 0.48 & 0.36 & 0.34 & 0.34 & 0.26 & 0.20 & 0.57 & 0.20 & 0.41 & 0.46 & 0.69 & 1.52 & 0.18 & 0.21 & 0.24 \\
\hline
\end{tabular}

be challenging. Thus, while I might predict some features of the fracture network in relation to the different structural positions within the fault zone, it is far more difficult to determine how persistent these features are in three dimensions.

\section{ACKNOWLEDGEMENTS}

This material is based upon work supported by the Keck Geology Consortium and the National Science Foundation under Grant No. 1659322. Special thanks to my advisor, Dr. Ben Surpless, for his helpful advice and patience throughout this project. I would also like to thank Curtis Segarra, Charley Hankla, and Madison Woodley for making Utah an unforgettable experience.

\section{REFERENCES}

Cooke, M., Mollema, P., Pollard, D., and Aydin, A., 2000, Interlayer slip and joint localization in the East Kaibab Monocline, Utah: field evidence and result from numerical modelling, In Cosgrove, J., and Ameen, M., eds.: Forced Folds and Fractures, Geological Society, London, v. 169, p. 23-49.

Cowie, P.A. and Shipton, A.K., 1998, Fault tip displacement gradients and process zone dimensions: Journal of Structural Geology, v. 20, p. $983-997$.

Davatzes, N.C., and Aydin, A., 2003, Overprinting faulting mechanisms in high porosity sandstones of SE Utah: Journal of Structural Geology, v. 25 , p. $1795-1813$, doi: $10.1016 / \mathrm{S} 0191-$ 8141(03)00043-9.

Davis, G.H., 1999, Structural geology of the Colorado Plateau region of southern Utah: Geological Society of America Special Paper 342, 127 p.
Doelling, H.H, Davis, F.D., and Brandt. C.J., 1989, The geology of Kane County, Utah, Geology, Mineral Resources, Geologic Hazards: Utah Geological and Mineral Survey Bulletin 124, 192 p.

Ferrill, D.A., Stamatakos, J.A., and Sims, Darrell, 1999, Normal fault corrugation- implications for growth and seismicity of active normal faults: Journal of Structural Geology, v. 21, p. 10271038.

Gregory, H.E., 1951, The geology and geography of the Paunsaugunt region Utah: U.S. Geological Survey Professional Paper 226, p. 1-116.

Hintze, L.F., 1973, Geologic History of Utah: Brigham Young University Geology Studies 20, 181 p.

Johnson, K., Nissen, E., Saripalli, S., Arrowsmith, R., McGarey, P., Scharer, K., Williams, P., and Blisniuk, K., 2014, Rapid mapping of ultramafic fault zone topography with structure from motion: Geosphere, v. 10, p. 969 - 986.

McGinnis, R.N., Ferrill, D.A., Smart, K.J., Morris, A.P., Higuera-Diaz, C., and Prawica, D., 2015, Pitfalls of using entrenched fracture relationships. Fractures in bedded carbonates of the Hidden Valley fault zone, Canyon Lake Gorge, Comal County, Texas: American Association of Petroleum Geologists Bulletin, v. 99, p. 22212245.

Peterson, F., and Pipiringos, G., 1979, Stratigraphic relations of the Navajo Sandstone to Middle Jurassic formations, southern Utah and northern Arizona: Professional Paper, doi: 10.3133/ pp1035b. 
Reber, S., Taylor, W.J., Stewart, M., and Schiefelbein, I.M., 2001, Linkage and reactivation along the northern Hurricane and Sevier faults, southwestern Utah, in Erskine, M.C., Faulds, J.E., Bartley, J.M., and Rowley, P.M., eds., The geologic Transition, High Plateaus to Great Basin - a symposium and field guide: Utah Geological Association Publication 30 and Pacific Section American Association of Petroleum Geologists Guidebook GB 78, p. 379-400.

Rogers, C., Myers, D., and Engelder, T., 2004, Kinematic implications of joint zones and isolated joints in the Navajo Sandstone at Zion National Park, Utah: Evidence for Cordilleran relaxation: Tectonics, v. 23, TC1007, doi:10.1029/2001TC001329

Sargent, K.A. and Philpott, B.C., 1987, Geologic map of the Kanab quadrangle. Kane County, Utah, and Mohave and Coconino Counties, Arizona: U.S. Geological Survey Map GQ-1603.

Schiefelbein, I., 2002, Fault segmentation, fault linkage, and hazards along the Sevier fault, southwestern Utah [M.S. thesis]: Las Vegas, University of Nevada at Las Vegas, $132 \mathrm{p}$.

Sibson, R. H., 1987, Rupture interaction with fault jogs: American Geophysical Union: AGU, 37, p. 157-167, doi:10.1029/GM037p0157

Taylor, W.J., Stewart, M.E., Orndorff, R.L., 2001, Fault segmentation and linkage: examples from the Hurricane fault, southwestern U.S.A., in Erskine, M.E., Faulds, J.E., Bartley, J.M., and Rowley, P.D., eds., The geologic Transition, High Plateaus to Great Basin - a symposium and field guide: Utah Geological Association Publication 30 and Pacific Section American Association of Petroleum Geologists Guidebook GB 78, p. 113126. 